\title{
OPTIMASI EMULGEL MINYAK ATSIRI ADAS (Foeniculum vulgare Mill.) SEBAGAI ANTI JERAWAT
}

\author{
Nurrahman $\mathbf{A}^{1)}$, Gunawan Pamudji $\mathbf{W}^{1)}$, Endang Diyah Ikasari ${ }^{2)}$ \\ ${ }^{1}$ Faculty of Pharmacy, Universitas Setia Budi Surakarta, J1. Letjen Sutoyo, Mojosongo, Surakarta \\ 57127, Indonesia \\ ${ }^{2}$ Stifar "Yayasan Pharmasi Semarang, Letjend Sarwo Edie Wibowo Km. 1, Plamongansari, Semarang \\ 50192, Indonesia
}

Email: endangdiyahikasari@gmail.com

\begin{abstract}
Acne is a common skin problem. One factor that causes acne is the bacterium Propionibacterium acnes by infecting the skin, causing inflammation. Fennel essential oil (Foeniculum vulgare Mill.) Has potential as an antibacterial. This study aims to determine the combination effect of HPMC, propylene glycol and tween 80 which is formulated to be the optimum preparation of fennel essential oil emulgel with good stability as an anti-acne.

Oleum Foeniculi are identified by GC-MS to determine the content of chemical compounds and are tested in vitro against Propionibacterium acnes to find out the minimum inhibitory concentration (MIC). Formula optimization is carried out using the factorial design method.

The results showed that Foeniculum oil has content of Benzene, 1-methoxy-4- (2propenyl) (83.64\%), 1-Limonene (3.75\%) and Fechone (3.58\%) which have potential antibacterial properties against Propionibacterium acnes. Foeniculum oil with a concentration of $6 \%$ shows a MIC value of $1.7 \mathrm{~cm}$. The concentration of fennel essential oil is formulated into an optimum emulgel preparation with a combination of $4 \%: 10 \%: 10.99 \%$. of HPMC, propylene glycol, and tween 80
\end{abstract}

Keywords: Anti-acne emulgel, HPMC, Propylene glycol, Tween 80, Foeniculum oil

\section{PENDAHULUAN}

Jerawat adalah penyakit kulit yang biasa terjadi pada usia remaja. Penyakit ini terbatas pada folikel pilosebase kepala dan badan bagian atas karena kelenjar sebase di wilayah ini sangat aktif. Apabila folikel pilosebase tersumbat, maka sebum tidak dapat keluar dan terkumpul di dalam folikel sehingga folikel membengkak, dan terjadilah komedo yang merupakan bentuk permulaan dari jerawat (Tranggono 2007).

$$
\text { Propionibacterium acnes }
$$

merupakan bakteri Gram positif dan anaerob yang merupakan flora normal kelenjar pilosebasea. Peranan Propionibacterium acnes pada patogenesis acne vulgaris adalah memecah trigliserida, salah satu komponen sebum, menjadi asam lemak bebas sehingga terjadi kolonisasi Propionibacterium acnes yang memicu inflamasi. Antibodi terhadap antigen dinding sel Propionibacterium acnes meningkatkan respons inflamasi melalui aktivasi komplemen. Enzim 5-alfa reduktase, enzim yang mengubah testosteron menjadi dihidrotestosteron (DHT), memiliki aktivitas tinggi pada kulit yang mudah berjerawat, misalnya pada wajah, dada, dan punggung (Tahir, 2010).

Biji tanaman adas secara empiris digunakan sebagai obat batuk, antiseptik dan laksatif. Beberapa penilitian 
menunjukan bahwa ekstrak metanol buah adas, ekstrak etanol buah adas, dan minyak adas dengan konsentrasi ekstrak 100 $\mu \mathrm{g} /$ disc mempunyai aktivitas antibakteri terhadap Escherichia coli dengan diameter zona hambat masing-masing $14 \mathrm{~mm}$, $12 \mathrm{~mm}$, dan 16 mm (Gulfraz dkk., 2008). Penelitian Kaur dan Arora (2009) menyebutkan ekstrak air panas biji adas dan ekstrak aseton biji adas menunjukkan aktivitas antibakteri yang lebih baik daripada ekstrak air mendidih biji adas dan ekstrak heksan biji adas terhadap bakteri Enterococcus faecalis, Staphylococcus aureus, Escherichia coli, Salmonella typhi, Salmonella typhimurium 1, Salmonella typhimurium 2, dan Shigella flexneri.

Minyak atsiri merupakan salah satu hasil metabolisme dalam tanaman, yang terbentuk karena reaksi berbagai senyawa kimia dan air. Minyak atsiri mempunyai sifat mudah menguap dalam suhu kamar tanpa mengalami dekomposisi. Minyak atsiri larut dalam pelarut organik seperti alkohol, eter, petroleum, benzene dan tidak larut dalam air. Minyak atsiri adas diperoleh dari destilasi tanaman adas (Prakosa dkk., 2013). Minyak atsiri adas memiliki warna yang jernih yang menarik untuk dibuat sediaan gel atau krim.

Emulgel adalah emulsi baik itu tipe minyak dalam air maupun air dalam minyak, yang dicampurkan ke dalam basis gel. Emulgel memiliki sifat yang lunak, lembut, mudah dioleskan dan tidak meninggalkan lapisan berminyak pada permukaan kulit (Jones, 2010). Emulgel memiliki stabilitas yang lebih baik jika dibandingkan dengan serbuk, salep, dan krim, serta tahapan pembuatan yang pendek dan sederhana (Hardenia, dkk., 2014). Penelitian yang dilakukan oleh Inneke (1995) terhadap minyak biji adas dari kromatogram kromatografi gas (GC) mengidentifikasi 14 senyawa golongan monoterpen, fenol, dan keton. Yang termasuk golongan fenol adalah anetol dan iso anetol 58,52\%; golongan monoterpen terdiri dari $\alpha$-pinen $3 \%$, camphene $0.33 \%$, $\alpha$-limonene $3,5 \%$; sedangkan golongan keton adalah d-camphore $0,39 \%$, fenchone 26,7\%. Minyak atsiri dari buah $F$. vulgare menunjukkan efek antibakteri terhadap patogen bawaan makanan seperti Escherichia coli, Bacillus megaterium dan Staphylococcus aureus (Mohsenzadeh, 2007), E. coli 0157: H7, Listeria monocytogenes dan S. aureus (Dadalioglu dan Evrendilek 2004; Cantore dkk., 2004). Aktivitas antibakteri ekstrak buah adas ini lebih rendah dibandingkan minyak adas.

Dalam pembuatan emulgel perlu diperhatikan pemilihan komposisi bahan penyusunnya antara lain gelling-agent, humektan dan emulgatornya agar memperoleh sistem emulsi yang stabil sehingga sediaan emulgel yang dihasilkan juga baik. Hidroksipropil metilselulosa (HPMC) merupakan polimer gelling agent semi sintetik yang dapat mengembang terbatas dalam air, gel yang dihasilkan jernih, netral serta memiliki viskositas yang stabil pada penyimpanan jangka panjang. Rentang penggunaan HPMC dalam sediaan gel adalah 2-4\% (Rowe dkk., 2009). Propilen glikol merupakan salah satu bahan yang dapat mengikat air pada sediaan agar tidak menguap, menstabilkan sediaan, dan sebagai pelembab di kulit (Hendradi dkk., 2013). Propilen glikol mampu menahan penyerapan air pada sediaan dibandingkan dengan gliserin. Propilen glikol juga digunakan sebagai peningkat penetrasi ke kulit (Nurhakim 2010). Tween 80 termasuk emulgator nonionik karena 
sifatnya tidak toksik dan tidak mengiritasi kulit. Dengan demikian dilakukan optimasi formula emulgel minyak atsiri adas dengan metode Factorial Design untuk mengetahui pengaruh HPMC, Propilen glikol dan Tween 80 terhadap sifat fisik dan stabilitas emulgel.

\section{METODE PENELITIAN}

\section{Alat dan Bahan}

Alat-alat yang digunakan adalah, GC-MS, mikroskop optik, sterilisator, beaker glass, tabung reaksi, vial, autoklaf, cawan petri, timbangan, ose bulat, lampu bunsen, inkubator, mikropipet, jangka sorong, vortex, alat uji $\mathrm{PH}$, viskometer Rion VT-04, wadah gel, waterbath, vaccum rotary evaporator, dan ayakan.Bahan

Bahan-bahan yang digunakan adalah media agar Muller Hinton, aquadestillata steril, alkohol $90 \%$, suspensi P.acnes, minyak atsiri adas (Foeniculum oil), spirtus, HPMC, propilen glikol, nipagin, nipasol, tween 80 , span 80 .

\section{Identifikasi Profil Minyak Atsiri Adas (Foeniculum Oil) dengan GC-MS}

Minyak atsiri adas diperoleh dari proses penyulingan secara bertingkat agar dapat menghasilkan hasil yang maksimal. Hasil penyulingan minyak atsiri adas didapatkan berat jenis pada suhu $20^{\circ} \mathrm{C}$ adalah 0,891 dan indeks reaktifnya sebesar 1,4980. Perlu adanya uji lebih lanjut untuk mengetahui aktivitas antibakteri pada minyak adas dengan menggunakan GCMS.

Identifikasi sampel dilakukan dengan alat spektrofotometer UV-Vis, IR, dan GC-MS. Spektra UV-Vis sampel uji untuk mengetahui panjang gelombang maksimal ( $\lambda$ max) isolat. Spektra IR untuk mengetahui gugus fungsi senyawa isolat. Kromatogram GC dan spektra MS untuk mengetahui $\mathrm{m} / \mathrm{z}$ senyawa dan SI (Similar Index) dari senyawa isolat.

\section{Penentuan Nilai KHM}

Pembuatan seri konsentrasi dilakukan dengan mencampur zat aktif dengan pelarutnya. Minyak atsiri larut dalam pelarut organik, salah satunya DMSO 10\%, DMSO 10\% dipilih sebagai pelarut karena mempunyai keuntungan tidak toksik dan tidak mempunyai aktivitas terhadap bakteri sehingga tidak mengganggu kerja dari zat aktif. Seri konsentrasi yang akan digunakan untuk pengenceran minyak adas yaitu, $2 \%, 4 \%$, $6 \%$ dan $8 \%$.

Standar Mc Farland dibuat dengan mencampur 9,95 $\mathrm{ml}$ asam sulfat $\left(\mathrm{H}_{2} \mathrm{SO}_{4}\right)$ dengan $0,5 \mathrm{ml} \mathrm{BaCl}$ 1. Selanjutnya, tabung disegel dan digunakan untuk perbandingan suspensi bakteri dengan standar. Larutan baku 0,5 Mc Farland ekuivalen dengan suspensi bakteri $1 \times 10^{8}$ CFU/mL (Saeed dan Tariq; 997-1001).

Media agar Muller Hinton ditimbang sebanyak 38 gram, dilarutkan dalam aquadest steril sebanyak $1 \mathrm{~L}$ dengan cara dididihkan. Setelah larut, disterilkan dengan autoklaf, suhu $121^{\circ} \mathrm{C}$ selama 15 menit. Media dituangkan ke dalam cawan petri steril sampai ketebalan $9 \mathrm{~mm}$ dan ditutup dibiarkan memadat di suhu ruangan.

Bakteri yang digunakan pada penelitian ini adalah Propionibacterium acnes. Bakteri diambil dengan menggunakan satu ose bulat, kemudian dimasukkan ke dalam nutrient broth, selanjutnya diinkubasi $37^{\circ} \mathrm{C}$ selama 24 jam setelah 24 jam suspensi bakteri yang telah diinkubasi disesuaikan dengan standar 
larutan $0,5 \mathrm{Mc}$ Farland $\left(1 \times 10^{8} \mathrm{CFU} / \mathrm{mL}\right)$ dengan menambah aquades steril (Suswati dan Mufida, 2009).

Kadar hambat minimal dari clindamycin untuk bakteri $P$. acnes adalah $2 \mu \mathrm{g} / \mathrm{ml}$. Antibiotik diambil sebanyak $2 \mu \mathrm{g}$ dari sediaan tablet $150 \mathrm{mg}$ dan dilarutkan dengan $1 \mathrm{ml}$ aquadest steril hingga didapatkan $2 \mu \mathrm{g} / \mathrm{ml}$ (Suswati dan Mufida, 2009).

Minyak atsiri adas dibuat dalam beberapa konsentrasi yaitu 2\%, 4\%, $6 \%$, dan $8 \%$, kemudian media MHA yang sudah disterilkan dipersiapkan. Bakteri Propionibacterium acnes digoreskan pada permukaan media MHA yang sudah memadat. Media MHA kemudian dibuat sumuran sebanyak konsentrasi minyak atsiri. Masing-masing dipipet $50 \mu \mathrm{l}$ untuk setiap konsentrasi ke lubang sumuran. Kontrol positif menggunakan clyndamisin dan untuk kontrol negatif menggunakan DMSO 10\%. Inkubasi selama 12-16 jam dalam suhu $37^{\circ} \mathrm{C}$ dalam keadaan anaerob. Zona hambat diamati dan diukur dengan jangka sorong untuk menentukan nilai KHM.

\section{Optimasi Formula Emulgel Minyak Atsiri Adas}

Rancangan formula HPMC, propilen glikol, dan tween 80 berdasarkan metode Factorial Design tiga replikasi dengan respon viskositas, ukuran globul, $\mathrm{pH}$, dan aktivitas antibakteri (Tabel 1).

Tabel 1. Formula emulgel minyak atsiri adas

\begin{tabular}{|c|c|c|c|c|c|c|c|c|}
\hline \multirow{2}{*}{ Formulasi } & F1 & F2 & F3 & F4 & F5 & F6 & F7 & F8 \\
\hline & \multicolumn{8}{|c|}{$\%$} \\
\hline $\begin{array}{l}\text { Minyak atsiri } \\
\text { adas }\end{array}$ & 8 & 8 & 8 & 8 & 8 & 8 & 8 & 8 \\
\hline HPMC & 2 & 2 & 4 & 4 & 4 & 4 & 2 & 2 \\
\hline Propilen glikol & 1 & 10 & 1 & 1 & 10 & 10 & 10 & 1 \\
\hline Tween 80 & 15 & 15 & 1 & 15 & 1 & 15 & 1 & 1 \\
\hline Span 80 & 10 & 10 & 10 & 10 & 10 & 10 & 10 & 10 \\
\hline Nipagin & 0.3 & 0.3 & 0.3 & 0.3 & 0.3 & 0.3 & 0.3 & 0.3 \\
\hline Nipasol & 0.6 & 0.6 & 0.6 & 0.6 & 0.6 & 0.6 & 0.6 & 0.6 \\
\hline Aquades & \multicolumn{8}{|c|}{$100 \mathrm{ml}$} \\
\hline
\end{tabular}

Cara pembuatan emulgel dengan cara melarutkan minyak atsiri adas dengan DMSO 10\%. HPMC dikembangkan dalam aquadest panas diaduk hingga membentuk massa dalam wadah yang berbeda. Emulgator fase air (Hidrofilik) yaitu tween 80 dicampurkan dengan propilen glikol, nipagin dan nipasol. Emulgator fase minyak (Hidrofobik), yaitu span 80 dicampurkan dengan minyak atsiri yang sudah dilarutkan dengan pelarut DMSO $10 \%$.

Penetapan formula optimum dilakukan dengan memasukkan data respon uji mutu fisik dan aktivitas antibakteri 8 formula rancangan berdasarkan metode factorial design meliputi viskositas, ukuran globul, $\mathrm{pH}$, dan aktivitas antibakteri. 


\section{Pengujian Sediaan}

Uji organoleptik emulgel meliputi uji warna, bau, dan konsistensi dari sediaan emulgel yang sudah bercampur dengan basis untuk mengetahui secara fisik keadaan gel. Sediaan yang dihasilkan sebaiknya memiliki warna yang menarik, bau yang menyenangkan, dan kekentalan yang cukup agar nyaman untuk digunakan.

Uji viskositas sediaan emulgel dilakukan dengan menggunakan alat viscometer Cup and Bob, yaitu dengan mengisi sampel emulgel yang akan diuji pada Cup dan menempatkan rotor tepat berada di tengah-tengah mangkuk yang berisi sediaan. Rotor mulai berputar dan jarum penunjuk viskositas secara otomatis akan bergerak ke kanan kemudian setelah stabil, viskositas dibaca pada skala dari rotor yang digunakan (Yuliani, 2010)

Pengukuran $\mathrm{pH}$. Pemeriksaan $\mathrm{pH}$ diawali dengan kalibrasi alat $\mathrm{pH}$ meter menggunakan dapar $\mathrm{pH} 4$ dan $\mathrm{pH} 7$. Elektrode alat $\mathrm{pH}$ meter dimasukkan ke dalam sediaan gel, tunggu angka hingga stabil dan catat nilai $\mathrm{pH}$ yang ditunjukkan oleh $\mathrm{pH}$ meter.

Uji pengukuran diameter globul rata-rata menggunakan mikroskop optik. Emulgel diletakkan di atas kaca obyek dan ditutup dengan gelas penutup, kemudian diamati menggunakan mikroskop dengan perbesaran 100 kali. Terlebih dahulu dilakukan penyesuaian skala, kemudian diameter globul rata-rata dihitung dengan menggunakan rumus Edmundson lalu gambar di mikroskop difoto menggunakan kamera digital.

Rumus Edmundson :

Diameter rata-rata $=\left[\frac{\Sigma n d^{p+f}}{\Sigma n d^{f}}\right]^{1 / p}$

$\mathrm{n}=$ banyaknya partikel dalam kisaran ukuran $\mathrm{d}=$ satu dari garis tengah ekivalen

$\mathrm{p}=$ indeks arimatik $=1$

$\mathrm{f}=$ indeks frekuensi

Uji Antibakteri, sediaan emulgel minyak atsiri yang telah divariasi dengan kombinasi hpmc, propilen glikol dan tween 80 ditentukan dengan mengukur diameter hambat pertumbuhan bakteri $P$. acnes yang merupakan bakteri penyebab jerawat. Pengujian aktivitas antibakteri dilakukan dengan metode difusi padat yakni membuat sumuran pada media dengan diameter sumuran sebesar $5 \mathrm{~mm}$. Metode sumuran dipilih karena pengerjaan uji yang relatif mudah dan memungkinkan bahan uji sediaan gel dapat langsung bersentuhan dengan dinding media agar, sehingga akan lebih mudah dilihat secara visual daya hambat dengan pengukuran adanya zona radikal yaitu suatu daerah disekitar sumuran dimana bakteri dihambat oleh antibakteri (Jawetz dkk., 2005).

\section{Analisis Data}

Analisis data. Verifikasi persamaan yang diperoleh dengan metode desain faktorial dilakukan dengan (one sample $T$ test) (confidence interval 95\%, uji 2 sisi nilai $\mathrm{p}=0,005$ ) terhadap parameter yang diuji (viskositas, ukuran globul, $\mathrm{pH}$ dan aktivitas antibakteri) antara nilai teoritis dengan hasil percobaan, persamaan terverifikasi jika tidak terdapat perbedaan yang bermakna antara nilai hasil teoritis dan hasil percobaan formula optimum.

\section{HASIL DAN PEMBAHASAN Karakteristik Minyak Atsiri}

Uji organoleptis bertujuan untuk mendeskrispsikan warna, bau, rasa dan tekstur dari minyak atsiri adas. Minyak atsiri adas memiliki tektur encer seperti minyak, warna bening kekuningan, memiliki rasa pedas dan memiliki bau 
yang cukup khas. Minyak adas memiliki kelarutan tinggi dalam etanol, dan sulit untuk larut dalam air. Minyak atsiri adas memiliki $\mathrm{pH}$ asam yaitu sebesar 5,43 dengan diuji menggunakan alat $\mathrm{pH}$ meter. pH minyak atsiri masih dalam rentang yang cukup baik jika diaplikasikan secara langsung dengan kulit sehingga dapat diformulasikan dalam sediaan topikal. $\mathrm{pH}$ sediaan yang memenuhi kriteria $\mathrm{pH}$ kulit yaitu dalam interval 4,5 -6,5 (Tranggono dan Latifa, 2007).

$\begin{array}{rrr}\text { Minyak } & \text { adas } & \text { dianalisis } \\ \text { menggunakan } & \text { GC-MS } & \text { (Tabel }\end{array}$
menunjukkan persentase area kandungan anethole (Benzene, 1-Methoxy-4-(2Propenyl)-) sebesar 83,64 \%. Beberapa kandungan lain dalam minyak adas seperti
Fenchone (3,58 \%); Linalool (0,69\%); 1Limonene (3,75 \%); dan benzaldehyde $(0,41 \%)$. Hasil analisis GC-MS tersebut menunjukkan bahwa kadar anethole paling tinggi diantara kandungan lain. Hal ini disesuaikan dengan hasil penelitian sebelumnya. Penelitian sebelumnya menunjukkan bahwa kandungan Transanethol pada minyak atsiri adas sebesar 68,53\% (Diao et al, 2014). Beberapa hasil dari penelitian yang dilakukan oleh Diao et al (2014) selain besarnya trans anetol yang ditemukan dalam minyak atsiri pada penelitian sebelumnya ditemukan pula kandungan lain yang hampir sama dengan hasil uji GC-MS yang dilakukan, yaitu Fenchone sebesar 5,42\% dan Limonen sebesar $6,42 \%$.

Tabel 2. Hasil GC-MS Kandungan Senyawa Minyak Atsiri Adas

\begin{tabular}{|c|c|c|c|c|c|}
\hline Peak & R.Time & $\begin{array}{c}\text { Area } \\
\%\end{array}$ & Kandungan & $\begin{array}{c}\text { Peak Area \% } \\
\text { (Diao et al, 2014) }\end{array}$ & Kandungan \\
\hline 1 & 10.620 & 0,60 & $\begin{array}{l}\text { (1S)-2,6,6- } \\
\text { Trimethylbicyclo[3.1.1] } \\
\text { hept-2-ene }\end{array}$ & 0,42 & $\alpha$-Pinene \\
\hline 2 & 13.484 & 0,46 & .DELTA.3-Carene & 1,21 & $\delta$-3-Carene \\
\hline 3 & 14.204 & 3,75 & l-Limonene & 6,24 & Limonen \\
\hline 4 & 14.303 & 0,63 & 1,8-Cineole & 0,12 & $\alpha$-Phellandren \\
\hline 5 & 16.390 & 3,58 & Fenchone & 5,42 & Fenchone \\
\hline 6 & 16.694 & 0,69 & Linalool & 0,27 & $p$-Menth-1-en-4-ol \\
\hline 7 & 20.055 & 2,41 & $\begin{array}{l}\text { Benzene, 1-methoxy-4- } \\
\text { (2-propenyl)- (CAS) }\end{array}$ & 0,16 & Camphor \\
\hline 8 & 22.315 & 0,41 & $\begin{array}{l}\text { BENZALDEHYDE，4- } \\
\text { METHOXY- }\end{array}$ & 0,47 & Estragole \\
\hline 9 & 23.448 & 83,64 & $\begin{array}{l}\text { BENZENE,1METHO } \\
\text { XY-4-(2PROPENYL)- }\end{array}$ & 68,53 & Trans-anethole \\
\hline 10 & 25.583 & 2,31 & $\begin{array}{l}\text { 1-Methoxy-4-(oxiran-2- } \\
\text { yl)methylbenzene }\end{array}$ & 0,18 & $\begin{array}{l}1-(p- \\
\text { Methoxyphenyl-2- } \\
\text { propanone }\end{array}$ \\
\hline 11 & 25.686 & 0,63 & ANISYL ACETONE & 0,31 & p-Anisaldehyde \\
\hline 12 & 26.784 & 0,67 & trans-Caryophyllene & 0,12 & isocaryopillene \\
\hline 13 & 27.051 & 0,21 & $\begin{array}{l}\text {.alpha.-Bergamotene } \\
\text { (CAS) }\end{array}$ & 0,47 & Cis-Anethole \\
\hline
\end{tabular}


Daya Hambat Minyak adas terhadap

\section{bakteri Propionibacterium acnes}

Dapat dilihat pada tabel 3 menunjukkan bahwa konsentrasi 6\% sudah memberikan rata-rata $17 \mathrm{~mm}$ dan dibandingkan dengan kontrol positif
(Klindamisin) yang memiliki daya hambat sebesar $14 \mathrm{~mm}$. Semakin besar konsentrasi maka semakin besar pula kandungan senyawa kimia yang bersifat antibakteri. Biji adas memiliki potensi sebagai antibakteri (Kusdarwati dkk., 2010).

Tabel 3. Pengamatan minyak adas terhadap Propionibacterium acnes dengan inkubasi anaerob selama 8 jam

\begin{tabular}{cccc}
\hline \multirow{2}{*}{$\begin{array}{c}\text { Konsentrasi } \\
(\%)\end{array}$} & \multicolumn{2}{c}{ Daya hambat terhadap } & \multirow{2}{*}{$\begin{array}{c}\text { Rata-Rata } \\
(\mathrm{mm})\end{array}$} \\
\cline { 2 - 3 } & Uji $(\mathrm{mm})$ & Uji II $(\mathrm{mm})$ & 7,5 \\
4 & 5 & 10 & 12 \\
6 & 12 & 12 & 17 \\
8 & 16 & 18 & 19 \\
- & 18 & 20 & - \\
+ (Klindamisin $)$ & - & - & 14 \\
\hline
\end{tabular}

\section{Uji Mutu Fisik Sediaan Emulgel}

Pengamatan organoleptis meliputi warna, aroma dan tekstur yang diamati secara visual. Hasil pengamatan organoleptis 8 formula sediaan emulgel minyak atsiri adas pada tabel 4 .

Tabel 4. Hasil pengujian organoleptis dan respon mutu fisik sediaan emulgel minyak atsiri adas

\begin{tabular}{|c|c|c|c|c|c|c|c|}
\hline \multirow[b]{2}{*}{ Formula } & \multicolumn{3}{|c|}{ Organoleptis } & \multicolumn{3}{|c|}{ Respon mutu fisik } & \multirow[b]{2}{*}{$\begin{array}{c}\text { Uji } \\
\text { aktivitas } \\
(\mathbf{m m})\end{array}$} \\
\hline & Warna & Aroma & Tekstur emulgel & $\begin{array}{c}\text { Viskositas } \\
\text { (cPs) }\end{array}$ & $\begin{array}{c}\text { Ukuran } \\
\text { globul } \\
\text { ( } \mu \mathrm{m})\end{array}$ & $\mathbf{p H}$ & \\
\hline 1 & $\begin{array}{l}\text { Putih } \\
\text { susu }\end{array}$ & $\begin{array}{l}\text { Minyak } \\
\text { Adas }\end{array}$ & $\begin{array}{l}\text { Lembut, kental dan } \\
\text { tidak lengket }\end{array}$ & 1940 & 5.87 & 4.25 & 19 \\
\hline 2 & $\begin{array}{l}\text { Putih } \\
\text { susu }\end{array}$ & $\begin{array}{l}\text { Minyak } \\
\text { Adas }\end{array}$ & $\begin{array}{l}\text { Lembut, kental dan } \\
\text { tidak lengket }\end{array}$ & 1880 & 6.77 & 4.81 & 24 \\
\hline 3 & $\begin{array}{l}\text { Putih } \\
\text { bening }\end{array}$ & $\begin{array}{l}\text { Minyak } \\
\text { Adas }\end{array}$ & $\begin{array}{l}\text { Lembut, kental dan } \\
\text { tidak lengket }\end{array}$ & 3355 & 5.62 & 4.93 & 15 \\
\hline 4 & $\begin{array}{l}\text { Putih } \\
\text { susu }\end{array}$ & $\begin{array}{l}\text { Minyak } \\
\text { Adas }\end{array}$ & $\begin{array}{l}\text { Lembut, kental dan } \\
\text { tidak lengket }\end{array}$ & 3223 & 5.83 & 4.52 & 18 \\
\hline 5 & $\begin{array}{l}\text { Putih } \\
\text { bening }\end{array}$ & $\begin{array}{l}\text { Minyak } \\
\text { Adas }\end{array}$ & $\begin{array}{l}\text { Lembut, kental dan } \\
\text { tidak lengket }\end{array}$ & 3323 & 5.76 & 5.43 & 17 \\
\hline 6 & $\begin{array}{l}\text { Putih } \\
\text { susu }\end{array}$ & $\begin{array}{l}\text { Minyak } \\
\text { Adas }\end{array}$ & $\begin{array}{l}\text { Lembut, kental dan } \\
\text { tidak lengket }\end{array}$ & 3055 & 5.86 & 4.91 & 23 \\
\hline 7 & $\begin{array}{l}\text { Putih } \\
\text { bening }\end{array}$ & $\begin{array}{l}\text { Minyak } \\
\text { Adas }\end{array}$ & $\begin{array}{l}\text { Lembut, kental dan } \\
\text { tidak lengket }\end{array}$ & 1930 & 6.67 & 5.24 & 16 \\
\hline 8 & $\begin{array}{l}\text { Putih } \\
\text { bening }\end{array}$ & $\begin{array}{l}\text { Minyak } \\
\text { Adas }\end{array}$ & $\begin{array}{l}\text { Lembut, kental dan } \\
\text { tidak lengket }\end{array}$ & 2041 & 6.12 & 5.11 & 17 \\
\hline
\end{tabular}

Keterangan : hasil rata-rata tiap formula dengan tiga kali replikasi 
Berdasarkan nilai koefisien (Tabel 5) HPMC merupakan komponen terbesar yang menyebabkan peningkatan viskositas, sedangkan propilen glikol mempunyai pengaruh paling besar menurunkan viskositas daripada tween 80. Untuk propilen glikol merupakan komponen terbesar yang menyebabkan meningkatnya ukuran globul, sedangkan HPMC dan tween 80 merupakan komponen terbesar yang berpengaruh menurunkan ukuran globul.

Berdasarkan nilai koefisien (Tabel 5) diketahui bahwa tween 80 merupakan komponen terbesar yang menyebabkan menurunkan $\mathrm{pH}$, sedangkan HPMC dan propilen glikol merupakan komponen terbesar yang berpengaruh meningkatkan $\mathrm{pH}$. Ketiga komponen HPMC, propilen glikol dan tween 80 berpengaruh menurunkan aktivitas.

Tabel 5. Nilai Koefisien masing-masing respon sediaan emulgel minyak atsiri adas

\begin{tabular}{|l|l|}
\hline \multirow{3}{*}{ Viskositas } & $\mathrm{Y}=+755.00000+652.97619(\mathrm{~A})-23.00000(\mathrm{~B})-6.88889(\mathrm{C})+5.13095(\mathrm{~A})(\mathrm{B})-$ \\
& $0.36508(\mathrm{~A})(\mathrm{C})+1.88889(\mathrm{~B})(\mathrm{C})-0.74206(\mathrm{~A})(\mathrm{B})(\mathrm{C})$ \\
\hline Ukuran & $\mathrm{Y}=+6.57048-0.24548(\mathrm{~A})+0.10024(\mathrm{~B})-0.057143(\mathrm{C})-0.020952(\mathrm{~A})(\mathrm{B})$ \\
Globul & $+0.018254(\mathrm{~A})(\mathrm{C})+6.42857 \mathrm{E}-003(\mathrm{~B})(\mathrm{C})-1.82540 \mathrm{E}-003 \mathrm{~A})(\mathrm{B})(\mathrm{C})$ \\
\hline $\mathrm{pH}$ & $\mathrm{Y}=+5.42032-0.12956(\mathrm{~A})-0.034603 \quad(\mathrm{~B})-0.10365 \quad(\mathrm{C})+0.022778 \quad(\mathrm{~A})(\mathrm{B})$ \\
& $+0.019008(\mathrm{~A})(\mathrm{C})+7.93651 \mathrm{E}-003(\mathrm{~B})(\mathrm{C})-2.22222 \mathrm{E}-003(\mathrm{~A})(\mathrm{B})(\mathrm{C})$ \\
\hline Aktivitas & $\mathrm{Y}=+19.44444-1.21429(\mathrm{~A})-0.51587(\mathrm{~B})-7.08969 \mathrm{E}-016(\mathrm{C})+0.17857(\mathrm{~A})(\mathrm{B})$ \\
& $+0.047619(\mathrm{~A})(\mathrm{C})+0.071429(\mathrm{~B})(\mathrm{C})-0.011905(\mathrm{~A})(\mathrm{B})(\mathrm{C})$ \\
\hline
\end{tabular}

Keterangan :

$\mathrm{Y}=$ Respon

$\mathrm{A}=\mathrm{HPMC}$

$\mathrm{B}=$ Propilen glikol

$\mathrm{C}=$ Tween 80

\section{Formula Optimum sediaan emulgel minyak adas}

Formula optimum yang didapatkan berdasarkan uji mutu fisik yang sudah dilakukan terhadap 8 formula.

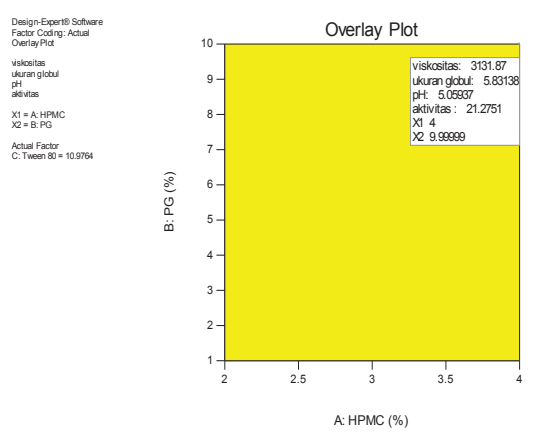

Gambar 1. Metode grafik analisi formula optimum sediaan emulgel minyak adas 


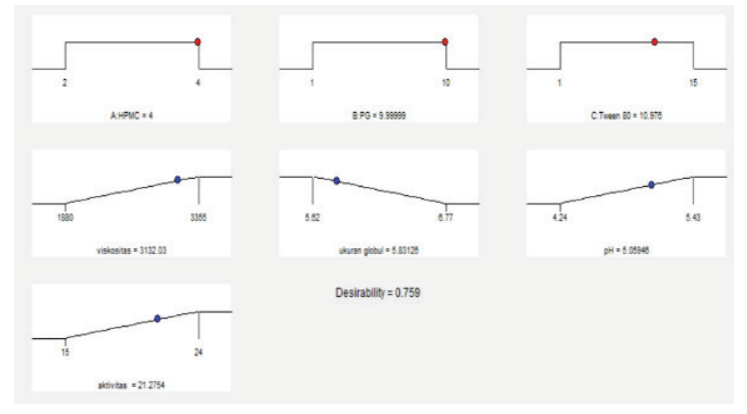

Gambar 2. Formula optimum sediaan emulgel minyak adas
Berdasarkan proses optimasi, kombinasi HPMC, propilen glikol, dan tween 80 sebesar 4\%:10\%: 10,99\%. menghasilkan nilai desirability 0,759 . Setelah penentuan formula optimum dengan menggunakan metode factorial design dan didapatkan hasil prediksi komposisi dan dibuat sediaan dengan 4 kali replikasi.

Tabel 6. Hasil uji Mutu Fisik Formula Optimum Sediaan Emulgel Minyak Adas

\begin{tabular}{|c|c|c|c|c|c|c|}
\hline \multirow{2}{*}{$\begin{array}{l}\text { Formula } \\
\text { sediaan }\end{array}$} & \multicolumn{3}{|c|}{ Organoleptis } & \multicolumn{3}{|c|}{ Respon Mutu Fisik } \\
\hline & Warna & Aroma & $\begin{array}{r}\text { Tekstur } \\
\text { emulgel }\end{array}$ & $\begin{array}{c}\text { Viskositas } \\
\text { (cPs) }\end{array}$ & $\begin{array}{c}\text { Ukuran } \\
\text { globul }(\mu \mathrm{m})\end{array}$ & pH \\
\hline 1 & $\begin{array}{l}\text { Putih } \\
\text { bening }\end{array}$ & $\begin{array}{l}\text { Minyak } \\
\text { Adas }\end{array}$ & $\begin{array}{l}\text { Lembut, } \\
\text { kental dan } \\
\text { tidak lengket }\end{array}$ & 2833 & 5,18 & 5,2 \\
\hline 2 & $\begin{array}{l}\text { Putih } \\
\text { bening }\end{array}$ & $\begin{array}{l}\text { Minyak } \\
\text { Adas }\end{array}$ & $\begin{array}{l}\text { Lembut, } \\
\text { kental dan } \\
\text { tidak lengket }\end{array}$ & 3476 & 6,1 & 4,8 \\
\hline 3 & $\begin{array}{l}\text { Putih } \\
\text { bening }\end{array}$ & $\begin{array}{l}\text { Minyak } \\
\text { Adas }\end{array}$ & $\begin{array}{l}\text { Lembut, } \\
\text { kental dan } \\
\text { tidak lengket }\end{array}$ & 3256 & 4,98 & 5,4 \\
\hline \multirow[t]{3}{*}{4} & $\begin{array}{l}\text { Putih } \\
\text { bening }\end{array}$ & $\begin{array}{l}\text { Minyak } \\
\text { Adas }\end{array}$ & $\begin{array}{l}\text { Lembut, } \\
\text { kental dan } \\
\text { tidak lengket }\end{array}$ & 2912 & 5,43 & 5,1 \\
\hline & Rata-rata & & & 3124,25 & 5,4225 & 5,125 \\
\hline & $\mathrm{SD}$ & & & 300,4789233 & 0,422396437 & 0,21650635 \\
\hline
\end{tabular}

Pengujian one sample t-test dilakukan untuk menguji perbedaan nilai parameter uji mutu fisik antara kelompok dengan respon prediksi dan percobaan pada tingkat minimum. Hasil one sample $t$ test dapat dilihat pada tabel 7 berikut :

Tabel 7. Hasil Uji One Sample T-Test

\begin{tabular}{lllll}
\hline Parameter Uji & Hasil Teoritis & Hasil Percobaan & Signifikasi & Kesimpulan \\
\hline Viskositas & $3132,03(\mathrm{cps})$ & 3124,25 & 0,068 & Tidak berbeda bermakna \\
Ukuran globul & $5,83 \mu \mathrm{m}$ & 5,42 & 0,069 & Tidak berbeda bermakna \\
pH & 5,06 & 5,13 & 0,170 & Tidak berbeda bermakna
\end{tabular}

Pada tabel 7 menunjukkan bahwa tidak terdapat perbedaan yang signifikan antara kelompok parameter uji mutu fisik prediksi dengan percobaan. Perbedaan yang tidak signifikan ditunjukkan melalui nilai thitung dan probabilitas pada setiap parameter uji dengan $p>0,05$. 


\section{SIMPULAN}

Berdasarkan hasil penelitian yang sudah didapatkan dapat disimpulkan bahwa minyak atsiri adas memiliki kandungan anethole cukup besar yaitu sebesar anetol (benzene, 1-methoxy-4-(2propenyl)-) sebesar 83,64\% dan memiliki beberapa kandungan lain seperti fenchone $(3,58 \%)$; dan 1-limonene $(3,75 \%)$, memiliki aktivitas sebagai antibakteri Propionibacterium acnes pada konsentrasi $6 \%$ dengan nilai KHM sebesar 1,6 cm. Hasil berdasarkan metode factorial design dengan aplikasi Design Expert 10 didapatkan formula optimasi dengan perbandingan HPMC, propilen glikol dan tween 80 sebesar \% : 10\%: 10,99\% dengan nilai desirability 0,759 . Sediaan optimum emulgel minyak adas memiliki aktivitas sebagai antibakteri pada bakteri Propionibacterium acnes dengan rata-rata daya hambat sebesar $2,68 \mathrm{~cm}$.

\section{DAFTAR PUSTAKA}

Akbar, B. 2010. Tumbuhan Dengan Kandungan Senyawa Aktif Yang Berpotensi Sebagai Bahan Antifertilisasi. Edisi 1. Jakarta: Adabia Press.

Amstrong N, James K. 1996. Pharmaceutical Experimental Design and Interpretation,. London: Taylor \& Francis Publiser.

Bolton S, Bon C. 2004. Pharmaceutical Statistics. New york: Marcel Dekker, Inc.

Brown, R.G. 2009. Lectures Notes Dermatologi, Jakarta: Erlangga

Dadalioglu, I. dan Evrendilek, G.A. 2004. Chemical compositions and antibacterial effects of essential oils of Turkish oregano (Origanum minutiflorum), Bay laurel (Laurus nobilis), Spanish lavender (Lavandula stoechas L.), and Fennel (Foeniculum vulgare) on common foodborne pathogens. Journal of Agricultural and Food Chemsitry 52: 8255-8260.

Gulfraz, M., Mehmood, S., 2008. Composition and antimicrobial properties of essential oil of Foeniculum vulgare. $A J B$ 7: 4364-8

Inneke. 1995, Karakterisasi Sifat Fisiko Kimia dan Analisa Profil Deskriptif Flavor Minyak Biji adas (Foeniculum vulgare Mill). Skripsi. Fakultas Teknologi Pertanian IPB, Bogor.

Jawetz, E., Melnick, J. L., dan Adelberg, E. A., 2005, Mikrobiologi Kedokteran, diterjemahkan oleh Mudihardi, E., dkk, Edisi XXII, 317-318, 322, 353, 362, Penerbit Salemba Medika, Jakarta

Joshi, H. dan Parle, M., 2006. Cholinergic basis of memory/ strengthening effects of Foeniculum vulgare Linn. Journal of Medicinal Food, 9, 413417.

Kim, S.I., Chang, K.S., Yang, Y.C., Kim, B.S. dan Ahn, Y.J., 2004, Repellency of aerosol and cream products containing fennel oil to mosquitoes under laboratory and field conditions, Pest Management Science, 60, 1125-1130.

Kusantati H., 2008. Tata Kecantikan Kulit, Jilid 2. Jakarta: Direktorat Pembinaan Sekolah Menengah Kejuruan Direktorat Jendral Manajemen Pendidikan Dasar dan Menengah Departemen Pendidikan Nasional. 
Lee SH, Jeong SK, Ahn SK., 2006, An update of the defensive barrier function of skin, Yonsei Medical Journal, 47(3),293-306.

Lo-Cantore, P., Iacobellis, N.S., DeMarco, A., Capasso, F. dan Senatore, F., 2004, Antibacterial activity of Coriander sativum L. and Foeniculum vulgare Miller Var. vulgare (Miller) essential oils, Journal of Agricultural and Food Chemistry, 52, 7862-7866.

Miranti, L., 2009, Pengaruh Konsentrasi Minyak Atsiri Kencur (Kaempferia galangan) dengan Basis Salep Larut Air terhadap Sifat Fisik Salep dan Daya Hambat Bakteri Staphylococcus aureus secara In Vitro, Skripsi, Fakultas Farmasi, Universitas Muhammadiyah Surakarta.

Mohsenzadeh, M., 2007, Evaluation of antibacterial activity of selected Iranian essential oils against Staphylococcu aureus and Escherichia coli in nutrient broth medium, Pakistan Journal of Biological Science, 10, 3693-3697.

Mumpuni, Y., 2010, Cara Jitu Mengatasi Jerawat, Penerbit: Andi, Yogyakarta.

Nurhakim A S., 2010, Evaluasi pengaruh gelling agent terhadap stabilitas fisik dan profil difusi sediaan gel minyak biji jinten hitam (Nigella sativa Linn). Skripsi. Jakarta: Universitas Islam Negeri Syarif Hidayatullah.

Rowe R, Sheskey P, Waller P., 2009, Handbook of Pharmaceutical Exipients, Edisi Keenam. Washington DC, Pharmaceutical
Press and American Pharmacist Association.

Ruberto, G., Baratta, M.T., Deans, S.G. dan Dorman, H.J., 2000, Antioxidant and antimicrobial activity of Foeniculum vulgare and Crithmum maritimum essential oils, Planta Medica 66, 687-693.x

Santoso, B., 2012, Buku Pintar Perawatan Kulit Terlengkap, Jogjakarta: Buku Biru.

Singh, G., Maurya, S., de Lampasona, M.P., Catalan, C., 2006, Chemical constituents, antifungal and antioxidative potential of Foeniculum vulgare volatile oil and its acetone extract, Food Control 17, 745-752.

Tahir M., 2010, Pathogenesis of Acne Vulgaris: simplified. Journal of Pakistan Association of Dermatologists, 20(1), 93-97

Tranggono, R.I. dan Latifah, F. 2007, Buku Pegangan Ilmu Pengetahuan Kosmetik. Editor: Joshita Djajadisastra, Pharm., MS, Ph.D. Jakarta: Penerbit Pustaka Utama. Hal: 11 - 25, $165-166$.

Widiawati, W, 2014, Perbedaan Hasil Penyembuhan Kulit Wajah Berjerawat Antara Masker Lidah Buaya dengan Masker Non Lidah Buaya. e-Journal. 3(1), Fakultas Teknik Universitas Negeri Surabaya.

Winarsih, S., Ratnawati, R., dan Wulan, D. A., 2005, Efektivitas Ekstrak Adas Manis (Foeniculum vulgare Mill. var. dulce) Sebagai Antimikroba terhadap Methicilin Resistant Staphylococcus aureus, (online), (http://elib.ub.ac.id, diakses tanggal 13 Juli 2019). 